\title{
What to do with Alvar Aalto?
}

PAAJANEN Ilkka ${ }^{1, a^{*}}$

${ }^{1}$ Saimaa University of Applied Sciences, Finland

ailkka.paajanen@saimia.fi

Keywords: Alvar Aalto, renovation

\begin{abstract}
Alvar Aalto (1898 - 1976) has built about 200 buildings. In Finland the influence of the Aalto has been very strong, but also ambivalent, as Tommi Lindh, the head of Alvar Aalto Foundation, said in an interview in Rakennuslehti (Building Journal), "there was either admiration or it was taboo" [1]. How should we renovate these buildings? It is not easy to say, what to do with Alvar Aalto and his buildings. Let's take three cases: The Central City Library in Vyborg, Sunila area in Kotka and Nano laboratory in Otaniemi Campus in Espoo.
\end{abstract}

\section{The Central City Library in Vyborg}

The Central City Library in Vyborg was built just before the Second World War. "The building is a famous masterpiece of $20^{\text {th }}$ century Modernism, the tectonic forms are a result of functions and the architectural values are the essential object of preservation, conservation and restoration", as Maija Kairamo and Tapani Mustonen have written about the building [2].

The competition for the library was organised in 1927. Alvar Aalto won the competition with a classicist entry, in the next years he developed his design from classicism to functionalism. The library was built in 1934 - 1935. [3]

The former Finnish town was after the war one part of the Soviet Union. In the 50es the Soviet authorities decided that the building should be renovated. There were two possibilities: restoration in its former state or renovation on the basis on the requirements of Soviet architecture, in Socialist Realism or Stalinist style. In the middle of 50es the authorities decided that the facades are to be restored to their former appearance. The outcome of these renovations is not good, for example the flat roofs technique had not been mastered in the Soviet Union. [4.]

During the soviet era the building was in very bad condition. As Aalto visited the building in 1962, he commented: "The building exists but the architecture has gone" [5].
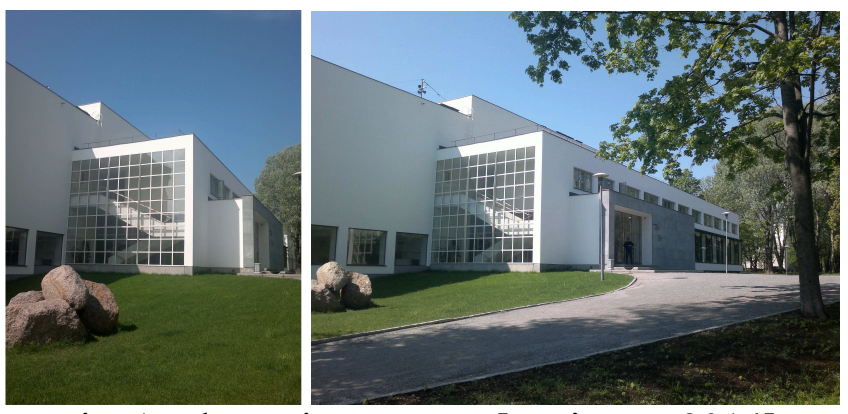

Fig. 1. The main entrance [Paajanen, 2014].

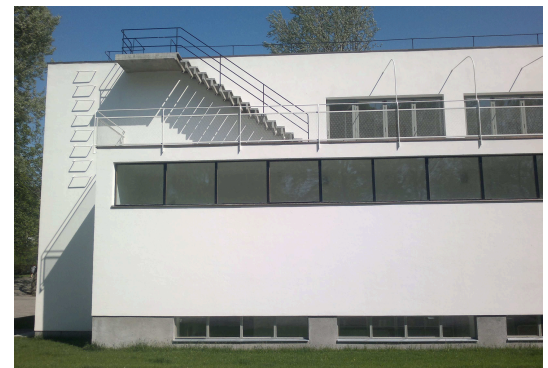

Fig. 2. The exterior stairs of the lending hall terrace [Paajanen, 2014]. 

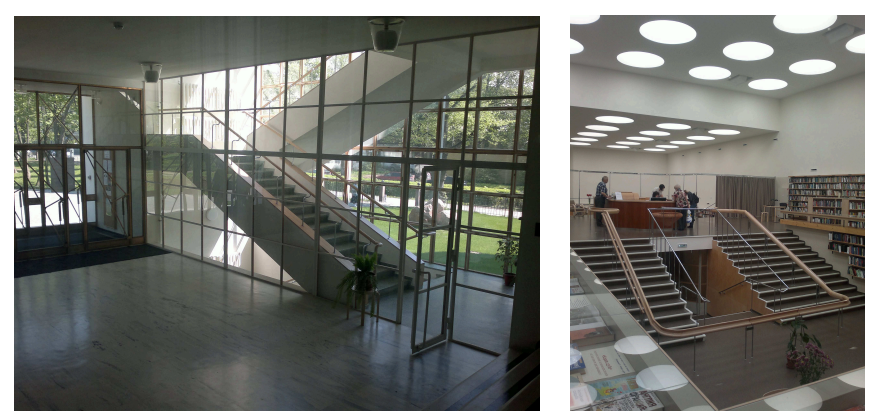

Fig. 3. The entrance lobby and the reading room [Paajanen, 2014].

During the last 20 years it has been renovated in Finnish-Russian cooperation. Now it (almost) looks like it was in the 30es. Should we have a building like this in his earlier presentation or should we see also the history of the building? Tapani Mustonen, the chief architect of the Library restoration project, said in the interview in the Finnish Architectural Review, that in Russia they tried to make everything so that the building would look like it did when it was new, in Finland they tried to save everything useful and to preserve also some solutions from the Soviet era, for example the layout of the cloakroom in the entrance lobby because they were more functional than the original [6].

\section{Sunila area}

Sunila area in the near of the town Kotka was built by the wood company Sunila Pulp Mill in the middle of the $20^{\text {th }}$ century. The company wanted to build one kind of a new factory area for a new age: the factory with a residential area for the employees. In Aalto's plan an open woodland area stretches between the buildings (see figure 4). There is a villa for the manager of the mill, row houses and apartment blocks for different kind of categories of employee. The plan is rather democratic, the open gardens between the buildings are open for everybody. The flats of the workers are small, in the flats there are toilets but not showers, originally there were some common sauna buildings. The architecture of the buildings is modern, for example the stepped apartment blocks Karhu and Päivölä are famous (see figure 5). [7.]
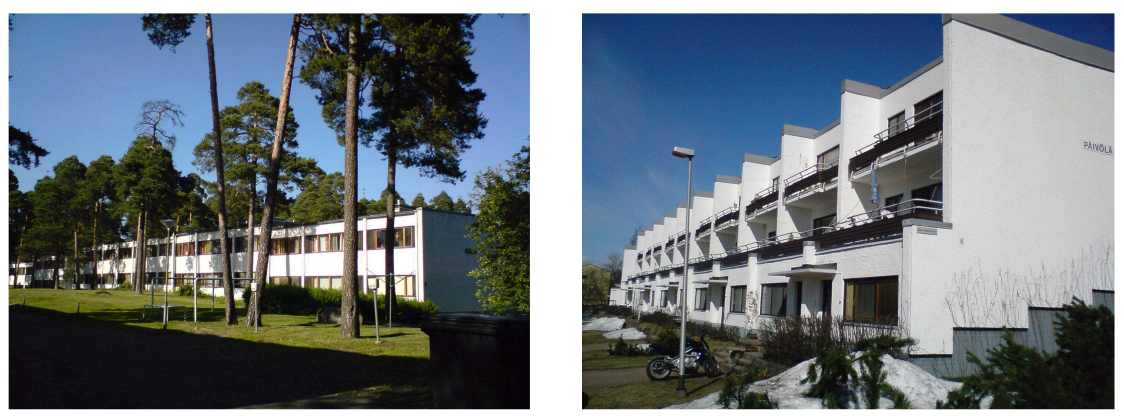

Fig. 4. Aparment block in Sunila [Paajanen, 2010].

Fig. 5. Karhu and Päivölä, stepped apartment blocks [Paajanen, 2010].

In the 60es the company sold the buildings. The situation especially in the 70es was miserable. The public bus and other connections from Sunila to the city of Kotka were not so good. The flats were small and in bad condition. The common saunas and heating centre have not more the original functions. What happens with building physics and the constructions, when the buildings are not in use or have other function (see figure 6)?

In the last decades the Pro Sunila society has worked for developing of the area and the flats. The society tries to organize all kind of activities for the people so that they could identify with the area. The society tries to protect and develop also the architecture. For example there are plans to make from two or three small flats a big one with bigger showers etc., so that also families with small children could better live in the area. The society has made guidelines for renovations, how to 
protect also the architectural details. Before that the owners of the stepped apartment blocks Karhu and Päivölä have chanced the parapet capping during the renovation (see figure 5).

How can we develop an area? It's easy to renovate one building, but when every building has different owners it is not easy to say what you can and may do.

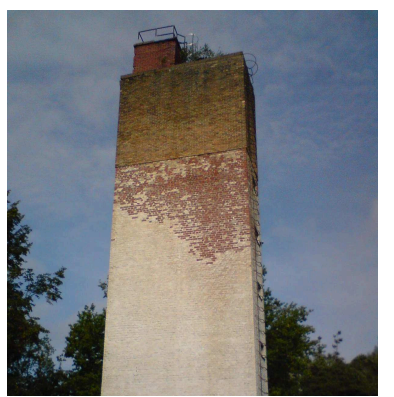

Fig. 6. Common heating centre [Paajanen, 2010].

\section{Nano laboratory building}

Alvar Aalto won the competition for the Otaniemi campus area of the Helsinki University of Technology in 1949 (situated in the neighbouring town Espoo) [8]. There are famous buildings like the main building and the library. Nowadays the university is called Aalto University.

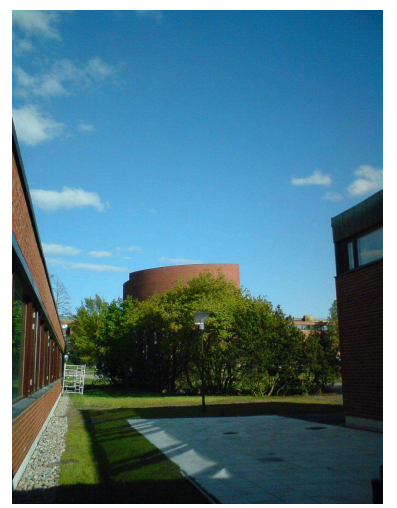

Fig. 7. Nano building in the front and the main building in the back [Paajanen, 2007].

Nano laboratory building was built in $60 \mathrm{es}$ as wood laboratory. There are many very fine architectural rooms and details in the building, for example skylights, also in the laboratory rooms (see figure 8), the beautiful main lobby (see figure 9) and inner courtyard, so called "secret garden" (see figure 10).
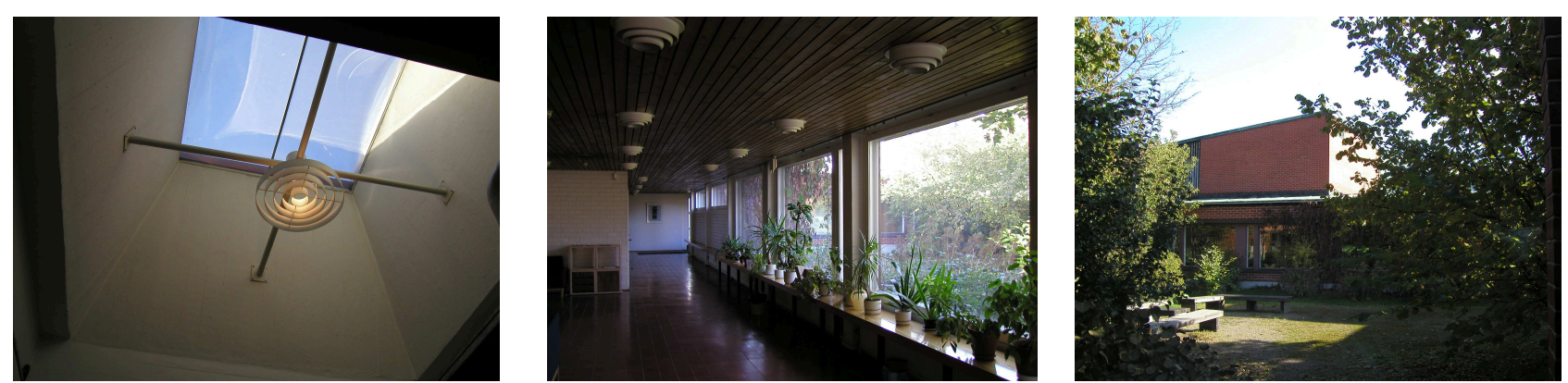

Fig. 8. Skylight in one laboratory room [Paajanen, 2004].

Fig. 9. Main lobby [Paajanen, 2004].

Fig. 10. "The secret garden", the inner courtyard [Paajanen, 2004].

For about eight years ago the building was renovated as nano laboratory with very special microscope laboratories, brain laboratories etc. We (I worked as the project architect of the 
renovation project) decided to have different areas: the lobby, the corridors, office rooms and other such kind of rooms belong to the most valuable areas, in the formal laboratory rooms (especially in the cases of the special laboratories) we could and should do more changes. In the best areas, for example in the lobby, it was one kind of restoration (or conservation), all old materials were "valuable", it was not always easy to find solutions for the new house technique.

How to renovate a laboratory building, when you should in the same time use renovation, conservation and build high tech laboratories?

\section{Restoration principles}

Does the restoration of a modernist building differ from the restoration of a historical building? Many restoration recommendations and doctrines have been developed for historical monuments.

In the case of modernist buildings the original architecture, constructions, materials etc. can still be there. Modernist architecture was minimal and the details are extremely important and sensitive. In the beginning of the modern architecture there was "the deep truth that modern science and technology could solve all problems" [9], but that means also that in this time they made many mistakes, for examples they copied in Finland many details from middle and south Europe, even the climatic conditions in Finland are quite different. Many flat roof and window details are problematic, for example parapet capping can be too small, perhaps without eaves flashing, often there is not enough thermal insulation etc. Should we rebuild also these "wrong details"?

All buildings from Alvar Aalto are not as strong as Viipuri City Library. For example the Nano laboratory building is just a laboratory building of "second class", the main building and the library are more important in Otaniemi campus - that means not, that the architecture of the wood laboratory building is some kind of "second class architecture". Sunila area is a living area where the people should live a normal life. What are the differences between these kind of buildings, should we take always conservation, restoration or reconstruction as principles, when we have buildings from Alvar Aalto? What should we do with other buildings from the same architectural era? It is not easy to say, which buildings are valuable, so it is also not easy to say, what to do with Alvar Aalto and his all buildings...

\section{References}

[1] J. Aatsalo, Aallon perinnön suojelija (= Protector of heritage of Aalto), an interview with Tommi Lindh, Rakennuslehti (= Building Journal) 27.6.2014, Helsinki, pp. 30.

[2] M. Kairamo and T. Mustonen, The Restoration of Central City Alvar Aalto Library in Vyborg, in: For an Architect's Training, docomomo Journal 49 - 2013/2.

[3] E. Adlercreutz, L. Englund, M. Kairamo, T. Mustonen and V. Nava, Alvar Aalto Library in Vyborg, Saving a Modern Masterpiece, Helsinki, 2009, pp. 14 - 25.

[4] E. Adlercreutz, L. Englund, M. Kairamo, T. Mustonen and V. Nava, Alvar Aalto Library in Vyborg, Saving a Modern Masterpiece, Helsinki, 2009, pp. 34 - 36.

[5] E. Adlercreutz, L. Englund, M. Kairamo, T. Mustonen and V. Nava, Alvar Aalto Library in Vyborg, Saving a Modern Masterpiece, Helsinki, 2009, pp. 36 - 37.

[6] B. Netta, Viipuri Library restoration, in: Finnish Architectural Review 2/2014, Helsinki 2014, pp. $26-37$.

[7] P. Korvenmaa (editor), Alvar Aalto architect, volume 7, Sunila, Helsinki, 2004.

[8] M. Hipeli (editor), Alvar Aalto architect, volume 13, University of Technology, Otaniemi. Helsinki, 2008.

[9] E. Adlercreutz, L. Englund, M. Kairamo, T. Mustonen and V. Nava, Alvar Aalto Library in Vyborg, Saving a Modern Masterpiece, Helsinki, 2009, pp. 50 - 52. 